\title{
1 Native seed addition as an effective tool for post-invasion restoration
}

2 Anna Bucharova ${ }^{a^{*}}$ and František Krahulec ${ }^{b}$

3

$4 \quad{ }^{a}$ Biodiversity and Ecosystem Research Group, Institute of Landscape Ecology, University of Münster,

5 Münster, Germany

$6{ }^{b}$ Institute of Botany, Czech Academy of Science, Pruhonice, Czech Republic

7

8 * Corresponding author: Tel. +49 2518339 766; fax: +49 2518338338

9 E-mail address: anna.lampei-bucharova@uni-muenster.de

10 Biodiversity and Ecosystem Research Group, Institute of Landscape Ecology, University of Münster,

11 Heisenbergstr. 2, 48149 Münster, Germany.

12 


\section{Abstract} Invasive plant species reduce biodiversity, alter ecosystem processes, and cause economic losses.

15 Control of invasive plants is therefore highly desired by land managers and policy makers. However, 16 invasive plant control strategies frequently fail, partly because management often concentrates only on

17 the eradication of invasive plants and not on revegetation with native species that use the available resources and prevent reinvasion. In this study, we focused on the intracontinental invader Rumex alpinus L., which was introduced by humans from the Alps to the lower mountains of Central Europe,

20 where it has spread to semi-natural meadows, suppresses local biodiversity, and reduces the quality of

21 hay used as cattle fodder. The species can be effectively removed using herbicide, but this leaves behind

22 a persistent seed bank. Without further treatment, the invader rapidly regenerates and reinvades the

23 area. We supplemented the herbicide treatment by adding the seeds of native grasses. Addition of

24 native-seed effectively suppressed the regeneration of the invader from the seed bank, reduced its

25 biomass, and consequently, prevented massive reinvasion. While the invader removal was successful,

26 the restored community remained species-poor because the dense sward of native grasses blocked the

27 regeneration of native forbs from the seed bank. Nevertheless, the addition of native seed proved to be

28 an effective tool in preventing reinvasion after the eradication of the invasive plant.

30 Keywords: alien species; invasive plant control; herbicide; seed bank; revegetation invader; Rumex

31 alpinus; seed limitation. 
34 Biological invasions cause ecological and economic impacts around the globe, including biodiversity losses (Hejda, Pyšek, \& Jarošík, 2009; Vilà et al., 2011), changes in ecosystem processes and services invasive species, and subsequent restoration of the habitat (Pyšek \& Richardson, 2010). after mechanical eradication, they are able to regrow from the small vegetative fragments of rhizomes, roots, or stolons that have been left behind (e.g., Klimeš, Klimešová, \& Osbornová, 1993; Kollmann,

47 successful, for example after herbicide treatment, many invasive plants leave behind a legacy that challenges restoration, for example in the form of physical or chemical alterations to the habitat or a buried seed bank (Corbin \& D’Antonio, 2012; Loydi, Donath, Eckstein, \& Otte, 2015). As the seeds of invasive plants generally survive longer in the soil than seeds of native congeners, soil seed banks contain a high proportion of invasive species (Drake, 1998; Gioria, Pyšek, \& Moravcová, 2012). Thus,

52 seeds buried in the soil can be the source of a rapid reinvasion of the space freed by the removal of 53 vegetative plants. Management of seed banks is usually not effective (Cohen et al., 2018), so post54 invasion restoration requires the filling of the space that was emptied by the removal of the invader, 
In ecological restoration, native species are frequently introduced in the form of seeds (Hölzel,

57 Buisson, \& Dutoit, 2012). Seed addition has proven to be an effective tool in post-mining restoration

58 (Ballesteros et al., 2012; Kirmer, Baasch, \& Tischew, 2012), the reestablishment of the semi-natural

grasslands on former croplands (Coiffait-Gombault, Buisson, \& Dutoit, 2012; Mitchley, Jongepierová, \&

Fajmon, 2012), or as a supplement to planting in forest restoration (Ceccon, González, \& Martorell,

2016). On the other hand, seed addition in post-invasive restoration has had mixed success (Petrov \&

Marrs, 2000; Pyke, Wirth, \& Beyers, 2013; Wilson \& Pärtel, 2003), suggesting that this is a critical area

for research in order to promote establishment of native species and prevent repeated invasions

64 (Kettenring \& Adams, 2011).

We focused on an intracontinental invader Rumex alpinus (also known as Alpine dock), a species species is considered a weed (Leuschner \& Ellenberg, 2018), but it has become especially troublesome in

72 its introduced range, where it grows at lower altitudes and is more vigorous (Štastná, Klimešová, \&

73 Doležal, 2012). In the Krkonoše Mountains, the species invades semi-natural meadows under the tree

74 line, where it creates large stands. These meadows were created by humans centuries ago as grasslands

75 traditionally used for hay production or grazing, and as such, they depend on mowing or grazing in order

76 to prevent natural succession towards forest. Such meadows are an inherent part of the cultural

77 landscape of Europe, and they typically host vast biodiversity and have a high a conservation value

78 (Bengtsson et al., 2019). The current large stands of $R$. alpinus in the Krkonoše Mountains originated

79 after World War II, when many mountain meadows were abandoned due to societal changes (Št'astná, 
Klimeš, \& Klimešová, 2010). Additionally, mountain chalets still lacked proper sewage treatment; their

81 vicinities were rather wet and nutrient-rich, and as such, the environment was optimal for the establishment of dense stands of $R$. alpinus. Although the nutrient input decreased several decades ago (Rehder, 1982), stands of $R$. alpinus persist and strongly suppress native biodiversity (Delimat \& Kiełtyk, 2019; Hejda, Pyšek, \& Jarošík, 2009). As the species is avoided by cattle (Bohner, 2005), the stands are useless for mountain farmers who may wish to mow the meadows for hay or as a pasture.

87 The target of such restoration is twofold: the reduction of the invader and the restoration of native biodiversity. While suppressing the invader will make the meadows once again suitable for haymaking or grazing, restoring community composition and native biodiversity will recreate the conservation value of these habitats. Once $R$. alpinus has established a dense stand on a former grassland, restoration of the area is problematic. The first necessary step is the return of traditional management practices for semi-cultural mountain meadows because its cessation was among the main causes of the invasion. However, simply

94 returning to traditional management is insufficient because R. alpinus has large storage rhizomes that 95 allow its rapid regeneration after the removal of aboveground biomass (Klimeš, Klimešová, \&

96 Osbornová, 1993). Burning, topsoil removal, chemical treatment, or very frequent mowing suppresses $R$.

97 alpinus (Šilc \& Gregori, 2016), but the species rapidly regenerates from a massive seed bank (Handlová \& 98 Münzbergová, 2006). Although seedlings of large docks are generally weak competitors and they are 99 sensitive to mowing (Hujerová, Pavlů, Hejcman, Pavlů, \& Gaisler, 2013; Zaller, 2004), seed banks contain 100 only a limited number of native seeds twhich are not sufficient for the rapid re-establishment of native 101 vegetation (Handlová \& Münzbergová, 2006). Thus, seed addition could be a possible tool for post102 invasion restoration. 
In this study, we tested whether the addition of native grass seed is a possible tool for restoring

104 mountain meadows after the eradication of $R$. alpinus. We hypothesized that (1) grass seedlings will

105 suppress R. alpinus seedlings, resulting in grass dominance on the restored plots and, thus, an increase

106 of biomass quality as fodder, and that (2) suppressing $R$. alpinus via seed addition will increase native

107 plant biodiversity.

108

\section{Materials and mathods}

110 The experiment was carried out at two sites in the Czech Republic's Krkonoše Mountains: Černá Voda (N

$\left.11150^{\circ} 44^{\prime} 04^{\prime \prime} \mathrm{N}, 9415^{\circ} 48^{\prime} 40^{\prime \prime E}\right), 950 \mathrm{~m}$ above sea level, and Klínovky (5042'32"N, 15³9'18"E), 1,200 m

112 above sea level. At each site, we selected vegetation with near $100 \%$ R. alpinus coverage. In early May

1132000 , we set up four pairs of experimental plots per site. Because a run-off from the neighbouring slope

114 damaged two pairs of plots at the Černá Voda site, we established an additional four pairs in 2001. In

115 total, the experiment comprised of ten pairs of plots. Each pair consisted of two $1.5 \mathrm{~m} \times 1.5 \mathrm{~m}$ plots next

116 to each other with $1 \mathrm{~m}$ of spacing. In June 2000 (2001 for the replacement plots), the stands of $R$.

117 alpinus were treated with a glyphosate-based herbicide (Roundup, Monsanto, concentration 5\%), which

118 completely destroyed the vegetation on the plots. Three weeks after the herbicide treatment, we added

119 grass seed to one random plot from each pair, while the other one remained without seed addition as a

120 control. The seeds were collected the previous year in the neighbourhood of the plots. Specifically, we

121 used a mixture of Alopecurus pratensis, Festuca rubra, and Agrostis capillaris in the densities of 500,

122560 , and 6,500 viable seeds per $\mathrm{m}^{2}$, respectively. We selected these species because they are common

123 at the sites and have easy-to-collect seeds, and the different densities were determined by seed

124 availability. The total seeding density approximately corresponds to high seed density recommended for

125 restoration in difficult conditions (https://www.rieger-hofmann.de). 
We monitored the vegetation for three consecutive years (two for plots established in 2001),

127 always in June. We used the core $1 \mathrm{~m} \times 1 \mathrm{~m}$ of each plot to avoid edge effects and divided it into to $3 \times 3$

128 subplots. For each subplot, we recorded all species of vascular plants and estimated their coverage using

129 the Braun-Blanquet scale. For the data analysis, we used the mean percentage cover of each unit ( "r, + "

$130=0.5 \%$; "1" -=3\%; "2" = 15\%; "3" = 37.5\%; "4" = 67.5\%; "5" = 87.5\%). At three randomly selected

131 subplots, we clipped the biomass $3 \mathrm{~cm}$ above ground, separated it to grass, forbs, and R. alpinus, dried it

132 for 48 hours at $70{ }^{\circ} \mathrm{C}$, and weighed it. We collected the biomass from the same subplots in all three

133 years of monitoring (two for plots established in 2001). The rest of the plot and the surrounding

134 vegetation were mown and the biomass was removed, as mowing is the traditional management

135 necessary to maintain the target community in semi-natural mountain meadows.

\section{Data analysis}

138 In the first step, we evaluated the effect of seed addition on vegetation cover and biomass composition 139 of the restored grasslands. We related (1) the proportion of biomass and (2) the cover of R. alpinus per

140 subplot to the seed addition treatment, the year since plot establishment, and the interaction of the two

141 variables in a linear mixed model. To account for the non-independency of the samples, we fitted site,

142 year of establishment, plot pair, and plot identity as nested random factors. As the variances within the

143 factors "seed addition" and "years since establishment" were not homogeneous (Levene test), we

144 estimated variance separately for each level of the respective factor using the function varComb of the R

145 package nlme (Pinheiro, Bates, DebRoy, \& Sarkar, 2018). We did not specifically test for the differences

146 between sites because we did not have enough independent replicates for such an analysis. Instead, we

147 kept site as a random factor and focused on the main effect of seed addition. We also ran the same

148 model for grass biomass (cover) and forb biomass (cover) as response variables. 
In the second step, we evaluated the effect of seed addition on plant biodiversity, represented

150

151

152

153

154

155

by the richness of native species. We related the number of native species per plot to seed addition, years since establishment, and their interaction in a model with the same structure as above. To

illustrate to what degree the diversity difference was driven by sowing species, we also ran the same model for native species, excluding the sown grasses.

\section{Results}

Seed addition had a profound impact on the vegetation of the plots. Without sowing, $R$. alpinus massively regenerated from the seed bank and constituted the majority of the biomass. In the first year, the unsown plots were rather variable and were dominated by native forbs and $R$. alpinus, whle forb biomass decreased over time. After three years, R. alpinus comprised $60-90 \%$ of the biomass (Fig. 1, Table 1). On the plots with seed addition, the sown grasses effectively suppressed $R$. alpinus and other forbs, and grasses comprised more than $90 \%$ of the total biomass in all three years (Fig. 1, Table 1). Although the biomass proportion of $R$. alpinus increased over time in the sown plots, it rarely reached more than $5-10 \%$ of the total plot biomass. Interestingly, the proportion of grasses increased in plots without seed addition as well (Fig. 1.). Results based on vegetation coverage largely confirmed the pattern observed for biomass (Fig. S1, Table S1).

We did not detect any effect of seed addition on the number of native species per plot. However, seed addition affected how species richness developed in time. While the number of species did not change over time in the unsown plots, it decreased in the plots with seed addition (Fig. 2 Table 1). Moreover, the majority of the native species in plots with seed addition were the sown grasses that suppressed almost all naturally regenerating native species (Fig. S2, Table S2).

\section{Discussion}


173 Invasive plant control often fails, partly because the removal of the invader is not followed by active

174 revegetation with native plants (Kettenring \& Adams, 2011). Here, we showed that an addition of native

175 grass seeds after herbicide application can effectively suppress invader regeneration and restore the

176 target community. Without seed addition, the invader regenerated from the seed bank and formed 60-

$17790 \%$ of biomass after three years, but seed addition reduced this number to less than $10 \%$. This method

178 is definitely the most effective control of R. alpinus (Šilc \& Gregori, 2016). Moreover, such success

179 exceeds the average reported in other studies on plant invasion control (Kettenring \& Adams, 2011). On

180 the other hand, the restored community was species-poor because sown grasses created dense sward

181 that suppressed other native species.

Invader suppression

There are three possible reasons why the control of invasive plant species was so effective in

this study. First, we focused on a biological invasion with a known underlying change in abiotic

conditions: in this case, cessation of traditional management. It was relatively straightforward to

reintroduce mowing and reestablish abiotic conditions as the prerequisite of any successful restoration

(McDonald, Gann, Jonson, \& Dixon, 2016). Second, we combined two suppression methods, i.e.,

herbicide treatment and seed addition. While this combination is relatively common in invasive species control, a success such as that in the present study is rare (e.g., Mahmood et al., 2018; Sheley, Mangold,

191 \& Anderson, 2006). Generally, a combination of methods is usually more successful than a single

192 method (e.g., Averill, DiTommaso, \& Morris, 2008; Baer \& Groninger, 2004; Dodson \& Fiedler, 2006;

193 Kilbride \& Paveglio, 1999). Third, detailed knowledge of the biology of both the invader and the target

194 community allowed us to design a restoration strategy that took advantage of the weaknesses of the

195 invasive species and the strengths of the native species. While adult $R$. alpinus plants are competitively

196 strong, its seedlings are weak and sensitive to mowing (Hujerová et al., 2013; Zaller, 2004). In contrast, 
197 European grasses, as dominants of semi-cultural meadows, have faced extensive mowing or grazing for

198 centuries and adapted to this type of disturbance. When clipped or mown, they often produce more

199 tillers, spread clonally, and form a dense ground cover that is competitively strong (Alexander \&

200 Thompson, 1982; Pecháčková, Hadincová, Münzbergová, Herben, \& Krahulec, 2010). This mechanism

201 allowed the sown grasses to suppress the seedlings of $R$. alpinus that regenerated from the seed bank.

Although seed addition significantly contributed to the suppression of $R$. alpinus, some plants

203

did regenerate, but they stayed rather small. In fact, the proportion of $R$. alpinus increased over time on

plots with added seeds. The question remains whether the few established dock plants will eventually

205

suppress the grasses and form dense stands. We believe such a scenario is unlikely as long as the

meadows are mown. The seedlings may still die due to competition from grasses, as mortality of dock

Even if the dock plants survive, they are unlikely to spread. Historically, R. alpinus grew for two centuries

211 stopped. Such a scenario may recur, and the cessation of mowing of the restored grassland may trigger

212 a reinvasion from the persistent seed bank (Handlová \& Münzbergová, 2006). Indeed, this happened to

213 the study plots when management was terminated with the end of the experiment in 2003. After a few

214 years without mowing, the restored $1.5 \mathrm{~m} \times 1.5 \mathrm{~m}$ grasslands were again taken over by a dense stand of

215 R. alpinus (A. Bucharova, personal observation).

\section{The effect on native biodiversity}

218 While seed addition suppressed $R$. alpinus, it did not have any positive effect on native

219 biodiversity. On the contrary, the sown grasses were competitively strong and thus prevented the

220 establishment of other species from the seed bank or seed rain. This is a common problem when grasses 
221 are seeded in high densities (Dickson \& Busby, 2009). A possible solution would be a more diverse seed

222 mixture. In this study, we collected seeds manually, and we restricted ourselves to the most common

223 grasses with easy-to-collect seeds. The more suitable alternative could be species-rich seed mixtures

224 produced by threshing local hay or commercial regional mixtures that are increasingly available

225 throughout Europe and other parts of the world (e.g., Bucharova et al., 2019; Breed et al., 2018, Kiehl,

226 Kirmer, Shaw, \& Tischew, 2014; Mitchley, Jongepierová, \& Fajmon, 2012). Another reason for the strong

227 grass dominance may be a high content of available nutrients in the soil. As $R$. alpinus produces a lot of

228 biomass that accumulates in the topsoil, the substrate is rich in humus and, thus, available nitrogen

229 (Bohner, 2005). Together with a possible legacy of increased phosphorus due to historical

230 eutrophication, the nutrient content in the soil could have allowed the grasses to be more productive

231 and to outcompete forbs (Hájek et al., 2017). With regular mowing and removal of biomass, the nutrient

232 content will decrease over time, althoght it may take decades (Oelmann et al., 2009). However, even in

233 that case, the addition of a species-rich seed mixture may be necessary to restore a diversity

234 comparable to the reference habitat of a species-rich mountain meadow (Stampfli \& Zeiter, 1999).

\section{Conclusion}

237 We have shown that the addition of native seeds is a powerful tool for post-invasive habitat restoration,

238 as the sown vegetation reduces reinvasion from the seed bank. It restores native vegetation cover and

239 ecosystem services in form of biomass suitable as cattle fodder. The success of this restoration measure

240 depended on the expert knowledge of the biology of both the invasive and native species, which

241 allowed us to design a method that used the weaknesses of the invader and the strengths of the local

242 species. This highlights the importance of research on invasive plants because lack of information on

243 species biology resulting in suboptimal management can be among the reasons why control invasive

244 plants and subsequent restoration often fail (Kettenring \& Adams, 2011). 


\section{Acknowledgment}

$247 \mathrm{AB}$ acknowledges that she collected the data while she was affiliated with the Charles University,

Prague. We are grateful to Zuzana Münzbergová and Tomáš Herben for inspiring scientific discussions and Christian Lampei for advice on data analysis. We thank Lubomír Jiriště for advice on plot selection and assistance with herbicide application, and we thank the Administration of Krkonoše National Park for support. AB thanks Tereza Michálková from the Botanical Library, Charles University, Prague, for assistance with resurrecting the data. We thank four anonymous reviewer for comments that improved this text. This work was supported by the Czech Academy of Sciences, Long-Term Research \&

\section{References}

257 Alexander, K. I., \& Thompson, K. (1982). The effect of clipping frequency on the competitive interaction between two perennial grass species. Oecologia, 53, 251-254.

Averill, K. M., DiTommaso, A., \& Morris, S. H. (2008). Response of pale swallow-wort (Vincetoxicum rossicum) to triclopyr application and clipping. Invasive Plant Science and Management, 1, 196206.

Baer, S. G., \& Groninger, J. W. (2004). Herbicide and tillage effects on volunteer vegetation composition and diversity during reforestration. Restoration Ecology, 12, 258-267. of Applied Ecology, 41, 1058-1064. 
Bengtsson, J., Bullock, J. M., Egoh, B., Everson, C., Everson, T., O’Connor, T., ... Lindborg, R. (2019). Grasslands-more important for ecosystem services than you might think. Ecosphere, 10, e02582.

Bohner, A. (2005). Rumicetum alpini Beger 1922 - species composition , soil-chemical properties, and mineral element content. Wulfenia, 12, 113-126.

Breed, M. F., Harrison, P. A., Bischoff, A., Durruty, P., Gellie, N. J. C., Gonzales, E. K., ... Bucharova, A. (2018). Priority actions to improve provenance decision making. BioScience, 68:510-516.

Bucharova, A., Bossdorf, O., Hölzel, N., Kollmann, J., Prasse, R., \& Durka, W. (2019). Mix and match: regional admixture provenancing strikes a balance among different seed-sourcing strategies for ecological restoration. Conservation Genetics, 20, 7-17.

Ceccon, E., González, E. J., \& Martorell, C. (2016). Is direct seeding a biologically viable strategy for restoring forest ecosystems? Evidences from a meta-analysis. Land Degradation and Development, $27,511-520$.

Cohen, O., Gamliel, A., Katan, J., Kurzbaum, E., Riov, J., \& Bar, P. (2018). Controlling the seed bank of the invasive plant Acacia saligna: comparison of the efficacy of prescribed burning, soil solarization, and their combination. Biological Invasions, 20, 2875-2887.

Coiffait-Gombault, C., Buisson, E., \& Dutoit, T. (2012). Using a two-phase sowing approach in restoration: sowing foundation species to restore, and subordinate species to evaluate restoration success. Applied Vegetation Science, 15, 277-289.

Corbin, J. D., \& D'Antonio, C. M. (2012). Gone but not forgotten? Invasive plants' legacies on community and ecosystem properties. Invasive Plant Science and Management, 5, 117-124.

Delimat, A., \& Kiełtyk, P. (2019). Impact of troublesome expansive weed Rumex alpinus on species diversity of mountain pastures in Tatra National Park, Poland. Biologia, 74, 15-24.

Dickson, T. L., \& Busby, W. H. (2009). Forb species establishment increases with decreased grass seeding density and with increased forb seeding density in a northeast kansas, U.S.A., experimental prairie 
restoration. Restoration Ecology, 17, 597-605.

294 Dodson, E. K., \& Fiedler, C. E. (2006). Impacts of restoration treatments on alien plant invasion in Pinus ponderosa forests, Montana, USA. Journal of Applied Ecology, 43, 887-897.

Drake, D. R. (1998). Relationships among the seed rain, seed bank and vegetation of a Hawaiian forest. Journal of Vegetation Science, 9, 103-112.

Gioria, M., Pyšek, P., \& Moravcová, L. (2012). Soil seed banks in plant invasions: Promoting species invasiveness and long-term impact on plant community dynamics. Preslia, 84:327-350.

Hájek, M., Dresler, P., Hájková, P., Hettenbergerová, E., Milo, P., Plesková, Z., \& Pavonič, M. (2017). grassland: A battle of species pools on mesic soils. Ecosystems, 20, 1233-1249.

Handlová, V., \& Münzbergová, Z. (2006). Seed banks of managed and degraded grasslands in the Krkonoše Mts., Czech Republic. Folia Geobotanica, 41, 275-288.

Hejda, M., Pyšek, P., \& Jarošík, V. (2009). Impact of invasive plants on the species richness, diversity and composition of invaded communities. Journal of Ecology, 97, 393-403.

Hölzel, N., Buisson, E., \& Dutoit, T. (2012). Species introduction - a major topic in vegetation restoration. Applied Vegetation Science, 15, 161-165.

Hongo, A. (1989). Transplant survival of Rumex obtusifolius L. and Rumex crispus L. in three old reseeded grasslands. Weed Research, 29, 13-19. and belowground biomass production of Rumex alpinus, R. crispus, R. obtusifolius and the Rumex hybrid ( R. patienta $\times$ R. tianschanicus ) in the seeding year. Weed Research, 53, 378-386.

314 IPBES. (2018). The IPBES assessment report on land degradation and restoration. (L. Montanarella, $\mathrm{R}$. 315 Scholes, \& A. Brainich, Eds.). Bonn: Secretariat of the Intergovernmental Science-Policy Platform on $316 \quad$ Biodiversity and Ecosystem Services. 
Kettenring, K. M., \& Adams, C. R. (2011). Lessons learned from invasive plant control experiments: A systematic review and meta-analysis. Journal of Applied Ecology, 48:970-979

Kiehl, K., Kirmer, A., Shaw, N., \& Tischew, S. (2014). Guidelines for native seed production and grassland restoration. Newcastle: Cambridge Scholars Publishing.

Kilbride, K. M., \& Paveglio, F. L. (1999). Integrated pest management to control reed canarygrass in seasonal wetlands of southwestern Washington. Wildlife Society Bulletin, 27:292-297. restoration of surface mined-land. Applied Vegetation Science, 15, 198-207.

Klimeš, L., Klimešová, J., \& Osbornová, J. (1993). Regeneration capacity and carbohydrate reserves in a clonal plant Rumex alpinus: effect of burial. Vegetatio, 109, 153-160.

Kollmann, J., Brink-Jensen, K., Frandsen, S. I., \& Hansen, M. K. (2011). Uprooting and burial of invasive

Leuschner, C., \& Ellenberg, H. (2018). Vegetation ecology of Central Europe. Springer International

Liao, C., Peng, R., Luo, Y., Zhou, X., Wu, X., Fang, C., ... Li, B. (2008). Altered ecosystem carbon and nitrogen cycles by plant invasion: a meta-analysis. New Phytologist, 177, 706-714.

Liu, J., Dong, M., Miao, S. L., Li, Z. Y., Song, M. H., \& Wang, R. Q. (2006). Invasive alien plants in China: role of clonality and geographical origin. Biological Invasions, 8, 1461-1470.

Lowe, S., Browne, M., Boudjelas, S., \& De Porter, M. (2000). 100 of the world's worst invasive alien species - A selection from the global invasive species database. The Invasive Species Specialist and growth of resident forbs and grasses: allelopathic, osmotic or mechanical effects? Biological 
Invasions, 17(2), 581-595.

Mahmood, A. H., Florentine, S., Graz, F. P., Turville, C., Palmer, G., Sillitoe, J., \& McLaren, D. (2018).

McDonald, T., Gann, G. D., Jonson, J., \& Dixon, K. W. (2016). International standards for the practice of ecological restoration - including principles and key concepts. Washington, D.C.: Society for Ecological Restoration.

Meyerson, L. A., \& D’Antonio, C. (2002). Exotic plant species as problems and solutions in ecological restoration: A synthesis. Restoration Ecology, 10, 703-713.

Mitchley, J., Jongepierová, I., \& Fajmon, K. (2012). Regional seed mixtures for the re-creation of speciesrich meadows in the White Carpathian Mountains: results of a 10-yr experiment. Applied Vegetation Science, 15, 253-263.

Oelmann, Y., Broll, G., Hölzel, N., Kleinebecker, T., Vogel, A., \& Schwartze, P. (2009). Nutrient impoverishment and limitation of productivity after 20 years of conservation management in wet grasslands of north-western Germany. Biological Conservation, 142, 2941-2948.

Pejchar, L., \& Mooney, H. A. (2009). Invasive species, ecosystem services and human well-being. Trends species-rich, nutrient-limited mountain grassland by mowing and fertilization. Restoration Ecology,

Petrov, P., \& Marrs, R. H. (2000). Follow-up methods for bracken control following an initial glyphosate in Ecology \& Evolution, 24, 497-504. application: The use of weed wiping, cutting and reseeding. Annals of Botany, 85, 31-35.

Pimentel, D. (2002). Biological Invasions. (D. Pimentel, Ed.). CRC Press. 
$R$ Development Core Team.

366

367

368

Pyke, D. A., Wirth, T. A., \& Beyers, J. L. (2013). Does seeding after wildfires in rangelands reduce erosion or invasive species? Restoration Ecology, 21, 415-421.

Pyšek, P., \& Richardson, D. M. (2010). Invasive pecies, environmental change and management, and health. Annual Review of Environment and Resources, 35, 25-55.

Rehder, H. (1982). Nitrogen relations of ruderal communities (Rumicion alpini) in the Northern Calcareous Alps. Oecologia, 55, 120-129.

Sheley, R. L., Mangold, J. M., \& Anderson, J. L. (2006). Potential for successional theory to guide restoration of invasive-plant-dominated rangeland. Ecological Monographs, 76, 365-379.

Šilc, U., \& Gregori, M. (2016). Control of alpine dock (Rumex alpinus) by non-chemical methods. Acta Biologica Slovenica, 56, 23-32.

Št’astná, P., Klimeš, L., \& Klimešová, J. (2010). Biological flora of Central Europe: Rumex alpinus L. Perspectives in Plant Ecology, Evolution and Systematics, 12, 67-79.

Stampfli, A., \& Zeiter, M. (1999). Plant species decline due to abandonment of meadows cannot easily be reversed by mowing. A case study from the southern Alps. Journal of Vegetation Science, 10, 151-164.

Štastná, P., Klimešová, J., \& Doležal, J. (2012). Altitudinal changes in the growth and allometry of Rumex alpinus. Alpine Botany, 122, 35-44.

Vilà, M., Espinar, J. L., Hejda, M., Hulme, P. E., Jarošík, V., Maron, J. L., ... Pyšek, P. (2011). Ecological impacts of invasive alien plants: a meta-analysis of their effects on species, communities and ecosystems. Ecology Letters, 14, 702-708.

Weber, E. (2011). Strong regeneration ability from rhizome fragments in two invasive clonal plants (Solidago canadensis and S. gigantea). Biological Invasions, 13, 2947-2955.

Wilson, S. D., \& Pärtel, M. (2003). Extirpation or coexistence? Management of a persistent introduced 
bioRxiv preprint doi: https://doi ora/10.1101/774331: this version posted October 29. 2019. The copvriaht holder for this preprint (which was not certified by peer review) is the author/funder, who has granted bioRxiv a license to display the preprint in perpetuity. It is made available under aCC-BY-NC-ND 4.0 International license. grass in a prairie restoration. Restoration Ecology, 11, 410-416.

390 Zaller, J. G. (2004). Ecology and non-chemical control of Rumex crispus and R. obtusifolius (Polygonaceae): a review. Weed Research, 44, 414-432. 
Fig. 1. The effect of seed addition on the proportion of biomass of Rumex alpinus, grasses and forbs, and its development over time since establishment of the plots. Plots on the left visualize results without seed addition and on the right after seed addition. Colored dots represent biomass values per subplots. Significant effects are shown in Table 1.
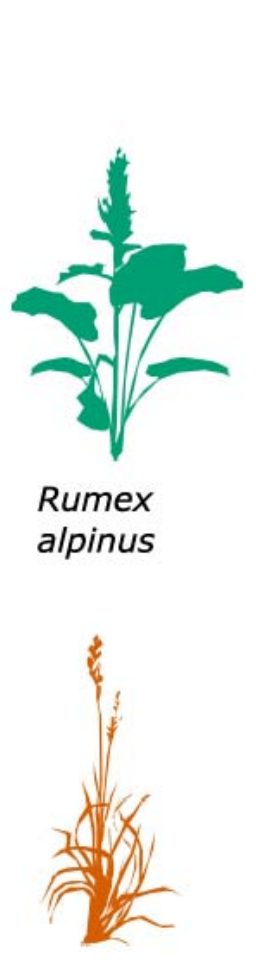

Grasses
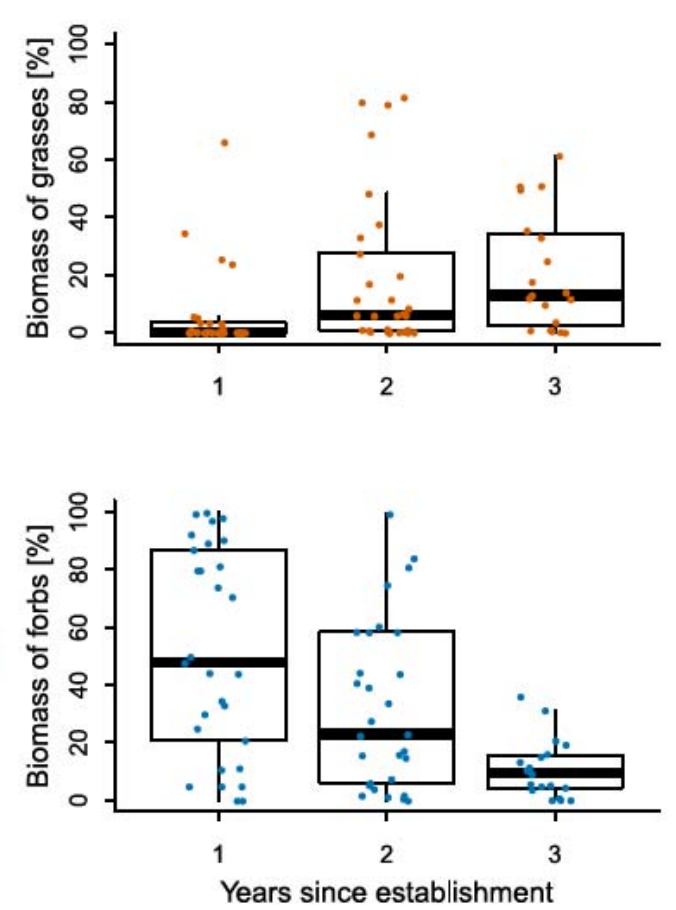
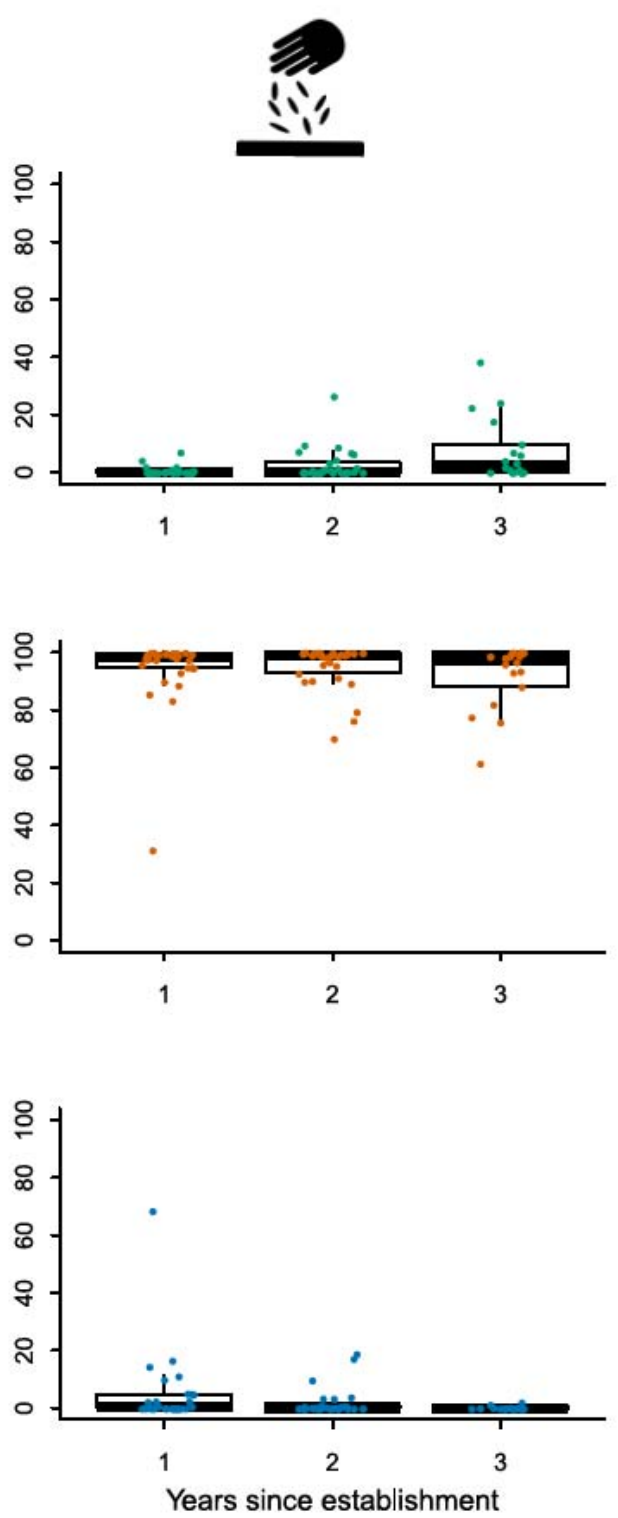
bioRxiv preprint doi: https://doi.org/10.1101/774331; this version posted October 29, 2019. The copyright holder for this preprint (which was not certified by peer review) is the author/funder, who has granted bioRxiv a license to display the preprint in perpetuity. It is made available under aCC-BY-NC-ND 4.0 International license.

Fig. 2. The effect of seed addition on native plant species richness, and the development of species richness over time since establishment of the plots. Plots on the left visualize results without seed addition and on the right after seed addition. Dots represent species numbers per subplots. Significant effects are shown in Table 1.
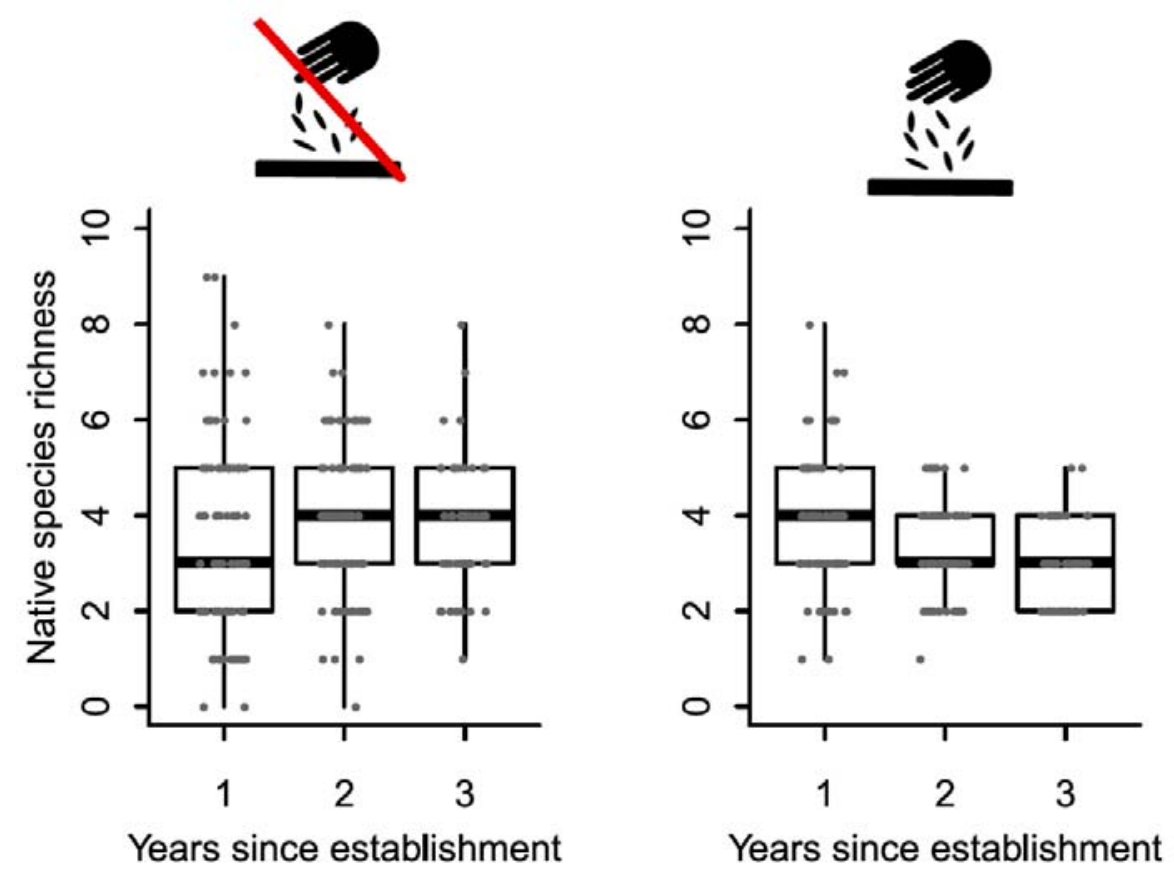
Table 1. The effect of seed addition and time since plot establishment on the proportion of biomass of Rumex alpinus, grasses and forbs, and the richness of native species. Results of ANOVA of linear mixed models, terms fitted sequentially, significant values $(P<0.05)$ are in bold.

\begin{tabular}{|c|c|c|c|c|c|c|c|c|c|c|c|c|}
\hline & \multicolumn{8}{|c|}{ Proportion of biomass } & \multirow{2}{*}{\multicolumn{4}{|c|}{ Native species richness }} \\
\hline & \multicolumn{4}{|c|}{ R. alpinus } & \multicolumn{2}{|c|}{ Grasses } & \multicolumn{2}{|c|}{ Forbs } & & & & \\
\hline & Num DF & Den DF & $\mathrm{F}$ & $P$ & $\mathrm{~F}$ & $P$ & $\mathrm{~F}$ & $P$ & Num DF & Den DF & $\mathrm{F}$ & $P$ \\
\hline Intercept & 1 & 91 & 4.87 & 0.030 & 256.80 & $<0.001$ & 12.32 & $<0.001$ & 1 & 281 & 25.10 & $<0.001$ \\
\hline Seed addition & 1 & 9 & 47.09 & $<0.001$ & 676.70 & $<0.001$ & 66.00 & $<0.001$ & 1 & 9 & 4.13 & 0.073 \\
\hline Years since & & & & & & & & & 2 & 281 & 1.09 & 0.337 \\
\hline establishment & 2 & 91 & 6.50 & 0.002 & 0.84 & 0.433 & 7.50 & $<0.001$ & & & & \\
\hline Seed addition $\times$ Years & 2 & 91 & 0.57 & 0.570 & 5.35 & 0.006 & 11.30 & $<0.001$ & 2 & 281 & 31.99 & $<0.001$ \\
\hline
\end{tabular}


FigureS1: The effect of seed addition on the cover of Rumex alpinus, grasses and forbs, and its development over time since establishment of the plots. Plots on the left visualize results without seed addition and on the right after seed addition. Dots represent cover per subplots. Significant effects are shown in Table S1.

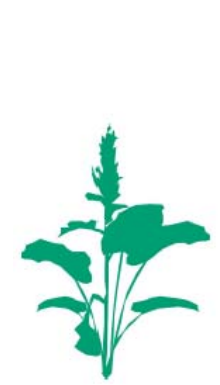

R. alpinus

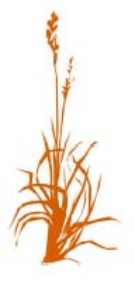

Grasses

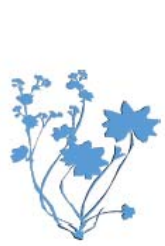

Forbs
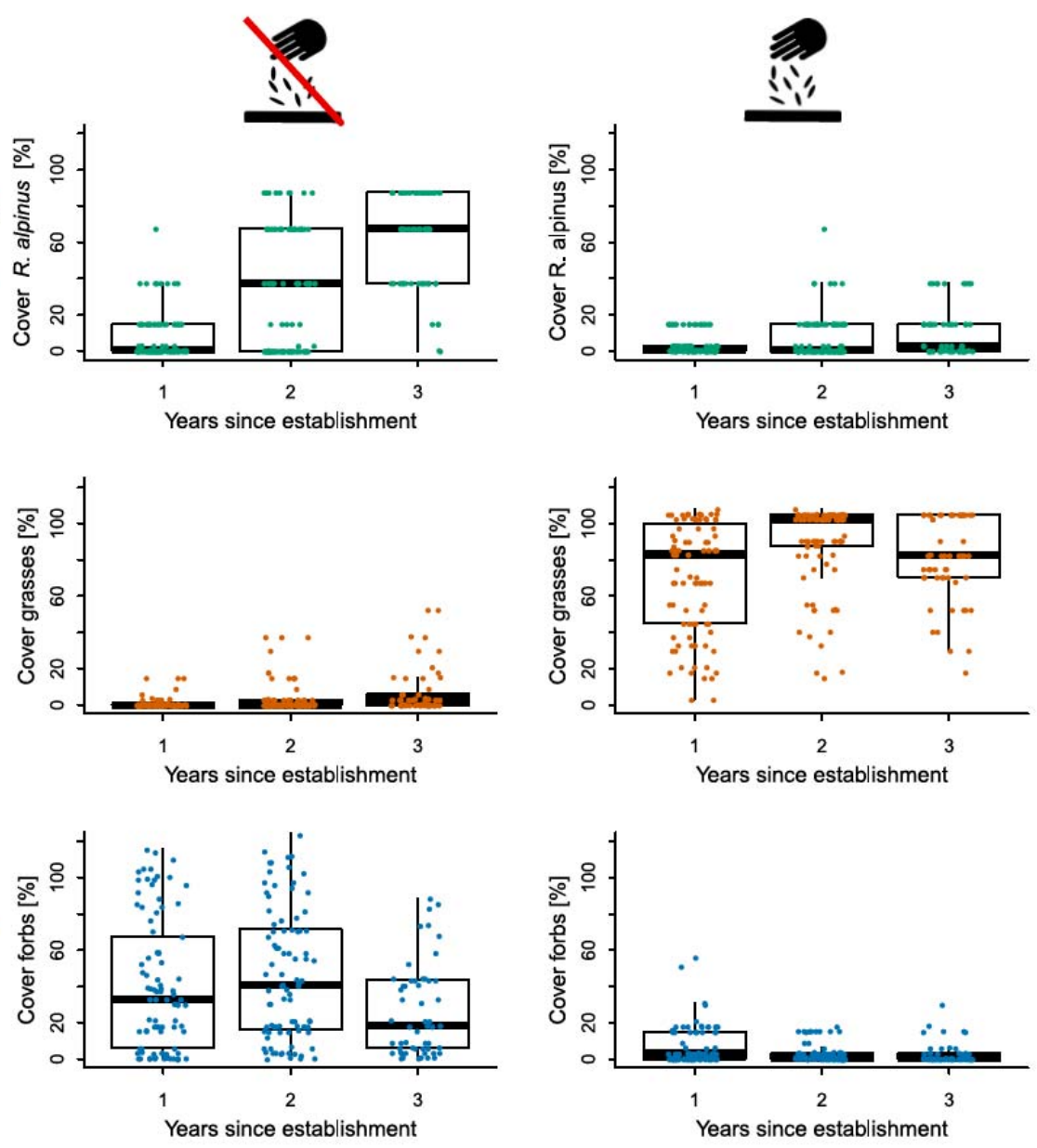
bioRxiv preprint doi: https://doi.org/10.1101/774331; this version posted October 29, 2019. The copyright holder for this preprint (which was not certified by peer review) is the author/funder, who has granted bioRxiv a license to display the preprint in perpetuity. It is made available under aCC-BY-NC-ND 4.0 International license.

Figure S2: The effect of seed addition on the species richness of native plants regenerating from the seed bank, and the development of species richness over time since establishment of the plots. Plots on the left visualize results without seed addition and on the right after seed addition. Dots represent species number per subplot. Significant effects are shown in Table 1.

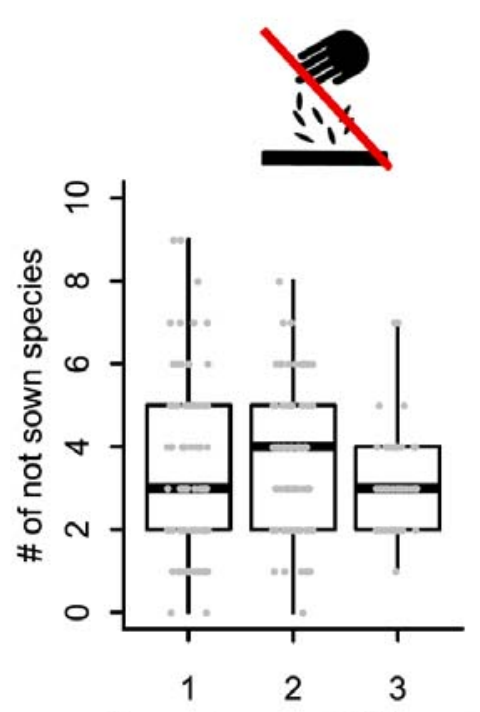

Years since establishment

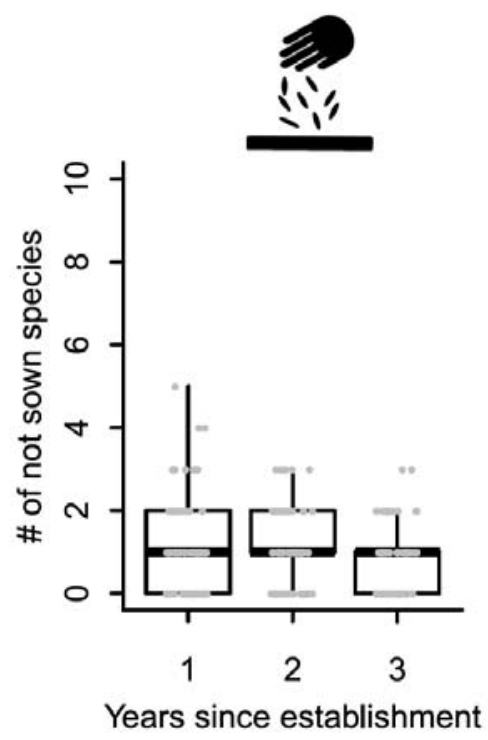


Table S1: : The effect of seed addition and the time since plot establishment on the cover of Rumex alpinus, grasses and forbs, and the richness of native species regenerating from the seed bank. Results of ANOVA of linear mixed models, terms fitted sequentially, significant values $(P<0.05)$ are in bold.

\begin{tabular}{|c|c|c|c|c|c|c|c|c|c|c|c|c|c|}
\hline & \multicolumn{8}{|c|}{ Cover } & \multirow{2}{*}{\multicolumn{5}{|c|}{$\begin{array}{l}\text { Native species richness } \\
\text { (sown species excluded) }\end{array}$}} \\
\hline & & & \multicolumn{2}{|c|}{ R. alpinus } & \multicolumn{2}{|c|}{ Grasses } & \multicolumn{2}{|c|}{ Forbs } & & & & & \\
\hline & Num DF & Den DF & F value & $P$ value & F value & $P$ value & F value & $P$ value & Num DF & & Den DF & F value & $P$ value \\
\hline Intercept & 1 & 281 & 5.02 & 0.026 & 18.56 & $<0.001$ & 2.92 & 0.089 & & 1 & 281 & 9.89 & 0.002 \\
\hline Seed addition & 1 & 9 & 15.40 & 0.003 & 237.00 & $<0.001$ & 24.17 & $<0.001$ & & 1 & 9 & 51.71 & $<0.001$ \\
\hline \multicolumn{14}{|l|}{ Years since } \\
\hline \multicolumn{14}{|l|}{ establishment } \\
\hline Seed addition $\times$ Years & 2 & 281 & 64.57 & $<0.001$ & 16.86 & 0.006 & 8.82 & $<0.001$ & & 2 & 281 & 0.78 & $<0.001$ \\
\hline
\end{tabular}

